\title{
Classification of foot shapes of young and middle-aged/elderly men
}

\author{
Ho Sun Lim $^{\dagger}$ \\ Dept. of Clothing \& Textiles, Sookmyung Women's University, Korea \\ 청년층과 중노년층 남성의 발 형태 분류 \\ 임 호 선 $^{+}$ \\ 숙명여자대학교 의류학과
}

\begin{abstract}
The present study analyzed data from the 3D measurement of the feet of men aged over 20 years residing in the capital region as part of the 6th Anthropometry of Size Korea. To analyze the characteristics of the foot shapes of young men aged 20 39 years and middle-aged/elderly men aged 40 69 years by age and by type, a cluster analysis was conducted using the factors derived through the factor analysis as independent variables. The results of the study that analyzed the characteristics of foot shapes by type according to differences in age were as follows. First, through the analysis of the characteristics of the foot shapes of young men by type, five factors were extracted, and the foot shapes were classified into three types: Type 1 (short and flat), Type 2 (thick), and Type 3 (long and wide). Second, through the analysis of the characteristics of the foot shapes of middle-aged/elderly men by type, six factors were extracted, and the foot shapes were classified into four types: Type 1 (short and regular), Type 2 (flat), Type 3 (thick), and Type 4 (long and regular). The results of the present study are expected to serve as basic data for the design of shoes by age and foot type.
\end{abstract}

Keywords: young men(청년 남성), middle aged and elderly men(중노년 남성), foot shape(발 형태), 3D scan(3 차원 스캔), shoes size(신발 사이즈)

\section{Introduction}

현대사회는 급속도로 산업화가 이루어지고 삶의 질이 향상되고, 인간의 수명이 증가되면서 중노년 인구도 지속적으로 증가하고 있으며, 웰빙과 건강에 대한 관심이 높아지고 있다(Kim, 2000; Lee, 1993). 중노년층의 경제 능력의 향상과 더불어 실버산업이 더욱 각광을 받고 있는 추세이다(Lee, 1993; Lee, 1996). 이와 함께 중년기에 접어들면서 점차적으로
노화현상이 진행됨에 따라 근골격계 기능저하, 체력 감소, 체형의 신체적인 변화가 일어나게 된다(Lee \& Chun, 2015). 또한 현대인들은 일상생활 중에 대부 분의 시간동안 착용하고 있는 신발의 기능성과 착 용감에 대한 관심이 지속적으로 증가하고 있다(Choi, Kweon, \& Kim, 2004; Chun \& Choi, 1999). 신발은 발을 보호하고, 보행 시 충격을 흡수해주는 역할을 하며, 발에 맞지 않는 신발을 착용했을 경우에는 발 의 피로감과 함께 장기간 착용했을 때는 발 형태의

Received 18 August 2015, revised 8 September 2015, accepted 18 September 2015.

본 연구는 숙명여자대학교 교내연구비지원에 의해 수행되었음(과제번호 1-1409-0005).

+ Corresponding author (lhs@sm.ac.kr) 
변형이 일어나기도 한다(Choi \& Chun, 2007; Kweon, Choi, \& Kim, 2005; Park \& Nam, 2004). 따라서 연 령에 따른 발에 적합한 신발을 제작하기 위해서는 발 크기, 형태와 특성에 대한 분석이 선행되어야 할 것이다.

이러한 발 형태에 대한 선행연구를 살펴보면, Kim and $\mathrm{Do}(2014)$ 는 광주광역시 지역의 60세 이상 남성 284 명을 대상으로 3 차원 인체측정을 실시하였고, 요 인분석 및 군집분석을 통하여 노년 남성의 발 형태 를 분류하였다. 3 차원 발 계측항목을 발길이에 대한 지수치로 분석한 결과, 7 개의 요인을 추출하였으며, 노년 남성의 발 형태를 발 앞부분이 높고 발중앙부 가 낮은 유형 1 , 발 앞부분이 낮고 발 중앙부가 높은 유형 2, 발 앞부분이 낮고 발 중앙부가 낮은 유형 3 으로 분류하였다. Seok, Park, Han, and Kim(2009)은 제 5 차 한국인 인체치수조사사업(Size Korea) 3 차원 인체 측정 자료 중 60 세 이상 70 세 미만의 노년 남 성과 20세 이상 30 세 미만의 청년 남성을 대상으로 연령별 발 유형의 특징을 비교분석하였다. 60 대와 20 대 남성의 발 형태 구성요인을 추출하기 위해 요 인분석한 결과, 60 대 남성은 7 개의 요인으로, 20 대 남성은 8 개의 요인으로 나타났다. 또한 60 대와 20 대 남성의 발 유형의 특징을 살펴보기 위해 군집분석을 실시한 결과, 60 대와 20 대 모두 3 개의 유형으로 분 류되었다. Lee and Kwon(2008)은 2005 Size Korea 사업의 3차원 스캔에 의한 발 데이터 자료 중 20 세 이상 성인 남성을 대상으로 발 형태 분류를 위한 요 인분석과 군집분석을 실시하였다. 그 결과, 20 세 이 상 성인 남성의 발 구성요인이 9개 요인으로 추출되 었으며, 4 개의 발 유형으로 분류되었다. 즉, 유형 1 은 두꺼운 발, 유형 2 는 작은 발, 유형 3 은 높은 발, 유형 4는 넓은 발의 형태로 구분하였다. 또한 20 대, 30 대, 40 대, 50 대, 60 대, 70 대 이상 연령대로 분류하 여 각 연령대에 따른 4 개의 유형의 분포율의 차이를 분석하였다. Seok and Park(2007)은 제5차 한국인 인체치수조사사업(Size Korea) 3차원 인체 측정 자 료 중 60세 이상 70세 미만 노년 남성을 대상으로 발 형태의 특징을 분석하였다. 인자분석과 군집분석 결과, 5 개 인자를 추출하였고, 발 형태를 3 개의 유형 으로 분류하였다. 또한 노년 남성의 발 유형 분석결 과에서 발너비, 발등둘레, 가쪽복사높이점의 이상 돌
출에 관한 특징을 고려해야 한다고 하였다. Lim and Choi(2005)는 대구 및 부산에 거주하는 14 16세 남 자 중학생 234 명을 대상으로 마틴계측법과 발 외곽 선측정법 등의 직접계측 및 간접계측을 실시하고, 요인분석과 군집분석을 통하여 청소년 남자 중학생 의 발 형태와 치수를 유형별로 분석하였다. 요인분 석과 군집분석 결과, 6 개 인자를 추출하였고, 발둘 레가 굵고 길이가 가장 긴 유형 1 , 발둘레, 길이와 높이가 가장 작은 유형 2 , 발둘레, 길이와 돌출정도 가 중간이며 발 높이는 가장 큰 유형 3 으로 분류하 였다. Park(2002)은 대구지역에 거주하는 초등학생 1 학년 남녀 총 105 명을 대상으로 발 측정을 실시하 였으며, 동일인이 1학년(1995년, 105명)때부터 3학 년(1997년, 105명), 5 학년(1999년, 78명)의 발과 하퇴 부 성장 특성에 관한 분석을 하였다. Shin and Hahm (1999)은 대구 및 경북 지역에 거주하는 20 29세 남 녀 414명을 대상으로 마틴계측법, Foot Print 측정 법, 발 외곽선 측정법과 발 기울기항목의 측정을 위 한 사진촬영법 등의 직접계측 및 간접계측을 실시 하고, 성인남녀 발 형태의 유형화 분석을 하였다. 성 별에 따른 발 계측치 평균의 차이를 분석한 결과, 볼 각도와 엄지측각도를 제외한 대부분의 항목에서 남 자의 계측치가 큰 경향을 나타내었다. 또한 성인 남 녀의 발 형태를 분석하기 위해 군집분석을 실시한 결과, 5개의 유형으로 분류하였다. Moon(1997)은 만 3세에서 6세의 남녀 유아 400 명을 대상으로 직접 계측과 간접계측을 실시하였고, 인자분석과 군집분 석을 통하여 유아의 발 형태를 분류하였다. 그 결과, 유아의 발 구성인자는 3 개의 인자로 추출되었으며, 발 형태는 4 개의 유형을 분류되었다. 이와 같이 유 아, 초등학생, 중고등학생, 청년층 남성의 발 형태에 관한 연구, 20 세 이상 30 세 미만의 청년과 60 세 이 상 70 세 미만의 노년 남성의 발 유형에 관한 비교연 구, 20세 이상 남성을 대상으로 모든 연령을 동질적 인 집단으로 유형을 분류한 연구, 60 세 이상 노년 남성의 발 형태에 관한 연구 등 다양한 연령층의 남 성을 대상으로 발 형태에 관한 연구가 활발히 이루 어졌으며, 청년층과 중노년층의 발 형태에 관한 연 구가 필요하다고 사료된다.

따라서 본 연구에서는 20 세 이상 성인 남성을 대 상으로 발계측 치수의 차이를 나타내는 청년층(20 
39세)과 중노년층(40 69세) 남성의 두 집단으로 분 류하여 연령별 발 형태의 유형화하고, 청년층과 중 노년층 소비자를 위한 연령별 발 형태에 적합한 신 발 설계를 위한 기초자료를 제공하고자 한다.

\section{Methods}

\section{Study subjects}

본 연구는 한국인 인체치수조사사업(Size Korea) 에서 2010년 6월 21일부터 12월 18일 동안 실시된 청년층 대상 제6차 한국인 인체치수 3 차원형상측정 조사사업의 자료와 2012년 8월 31일부터 12월 25일 동안 실시된 중노년층 3 차원 인체형상측정사업의 자료를 사용하였다. 연구대상은 수도권에 거주하는 20 39세 청년층 남성을 대상으로 측정한 438명 중 에서 자료가 미비한 3 명을 제외한 435 명의 자료를 분석에 이용하였다. 그리고 40 69세 중노년층 남성 을 대상으로 측정한 618 명 중에서 자료가 미비한 21 명을 제외한 597 명의 자료를 분석에 이용하였다.

\section{Measurement items}

한국인 인체치수조사사업(Size Korea)에서 K\&I Technology의 Enfoot System과 NexScan2의 3차원 발 스캐너로 측정한 발 측정항목 중 청년층과 중노 년층의 공통 측정항목 19 개 항목의 데이터를 사용
〈Table 1〉 Foot measurement item

\begin{tabular}{c|l}
\hline No. & \multicolumn{1}{|c}{ Items } \\
\hline 1 & Foot length \\
\hline 2 & Heel-to-toe 1 length \\
\hline 3 & Heel-to-instep length \\
\hline 4 & Foot breadth \\
\hline 5 & Ball distance \\
\hline 6 & Ball height \\
\hline 7 & Instep height \\
\hline 8 & Lateral malleolus height \\
\hline 9 & Heel height \\
\hline 10 & Height of upper point of heel point \\
\hline 11 & Ball circumference \\
\hline 12 & Instep circumference \\
\hline 13 & Heel-to-instep circumference \\
\hline 14 & Medial ball length \\
\hline 15 & Lateral ball length \\
\hline 16 & Ball center-to-toe 2 length \\
\hline 17 & Ball center-to-heel length \\
\hline 18 & Medial ball width \\
\hline 19 & Lateral ball width \\
\hline 2010$),$ & p 74. \\
\hline & \\
\hline 100 & Korean Agency for Technology and Standards \\
\hline 14
\end{tabular}

하였다. 또한 청년층과 중노년층 남성의 발 형상에 동일한 발 측정 기준점과 측정 방법으로 측정한 항 목은〈Fig. 1〉 및〈Table 1 과 같다.
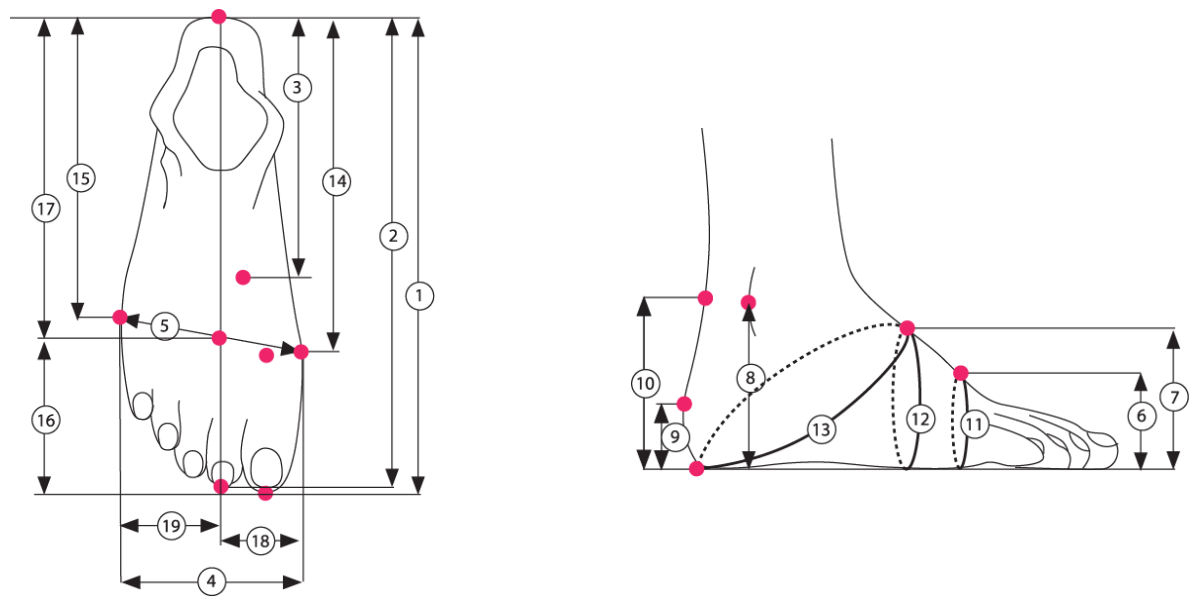

〈Fig. 1〉3D foot measurement items.

From. Korean Agency for Technology and Standards (2010), p 75. 


\section{Analysis method}

본 연구의 자료는 IBM SPSS Statistics 22 프로그 램을 사용하여 통계처리하였다. 청년층과 중노년 남 성 발 형태의 구성요인을 도출하기 위하여 요인분 석을 실시하였고, 발 형태를 유형별로 분류하기 위 하여 군집분석을 실시하였다. 분류된 유형별 차이를 살펴보기 위하여 각 측정항목의 평균값에 대하여 분산분석과 Duncan test 사후검증을 실시하였다.

\section{Results}

\section{Factors of young men's foot shape}

청년층(20 39세) 남성 발 형태의 구성요인을 도
출하기 위하여 요인분석을 실시하였다. 베리맥스 (Varimax) 방법으로 직교회전을 하여 고유치가 1 이 상인 것으로 요인 수는 최종 5 개의 요인이 추출되었 다. 〈Table 2〉은 청년층 남성의 발 계측치수에 대한 요인분석의 결과를 보여주며, 5 개의 요인이 설명할 수 있는 분산은 전체의 $82.02 \%$ 이다.

요인 1은 고유치가 5.71 이고, 전체변량의 $30.07 \%$ 를 설명한다. 발중심점하측길이(0.96), 발꿈치-발가 쪽점길이(0.91), 발꿈치-발안쪽점길이(0.89), 발길이 (0.85), 발꿈치-엄지 발가락길이(0.85), 발꿈치-발등길 이(0.79), 발꿈치-발등둘레(0.76)의 높은 적재값을 가 지며, 발길이에 영향을 미치는 요인으로 해석하여 길 이요인으로 명명하였다. 요인 2는 고유치가 4.56이

〈Table 2〉 Results of the factor analyses of measured feet dimensions of young men

\begin{tabular}{|c|c|c|c|c|c|}
\hline Items $\quad$ Factor & 1 & 2 & 3 & 4 & 5 \\
\hline 17 Ball center-to-heel length & 0.96 & 0.14 & 0.14 & 0.05 & -0.04 \\
\hline 15 Lateral ball length & 0.91 & -0.01 & 0.18 & -0.01 & 0.05 \\
\hline 14 Medial ball length & 0.89 & 0.22 & 0.07 & 0.10 & 0.04 \\
\hline 1 Foot length & 0.85 & 0.31 & 0.08 & 0.30 & 0.09 \\
\hline 2 Heel-to-toe 1 length & 0.85 & 0.31 & 0.08 & 0.29 & 0.10 \\
\hline 3 Heel-to-instep length & 0.79 & 0.34 & -0.20 & 0.26 & 0.04 \\
\hline 13 Heel-to-instep circumference & 0.76 & 0.48 & -0.02 & 0.21 & 0.04 \\
\hline 11 Ball circumference & 0.20 & 0.92 & 0.20 & 0.22 & 0.02 \\
\hline 5 Ball distance & 0.30 & 0.90 & 0.08 & 0.14 & 0.03 \\
\hline 4 Foot breadth & 0.37 & 0.87 & 0.14 & 0.09 & 0.04 \\
\hline 12 Instep circumference & 0.23 & 0.84 & 0.39 & 0.12 & 0.01 \\
\hline 7 Instep height & -0.06 & 0.20 & 0.89 & 0.06 & -0.07 \\
\hline 6 Ball height & 0.06 & 0.26 & 0.75 & 0.01 & -0.03 \\
\hline 8 Lateral malleolus height & 0.19 & -0.01 & 0.71 & 0.19 & -0.03 \\
\hline 10 Height of upper point of heel point & 0.20 & -0.05 & 0.15 & 0.68 & 0.01 \\
\hline 9 Heel height & 0.09 & 0.23 & 0.12 & 0.64 & 0.03 \\
\hline 16 Ball center-to-toe 2 length & 0.23 & 0.45 & -0.06 & 0.60 & -0.01 \\
\hline 18 Medial ball width & 0.28 & 0.37 & -0.03 & 0.07 & 0.87 \\
\hline 19 Lateral ball width & 0.13 & 0.57 & 0.17 & 0.03 & -0.78 \\
\hline Factor character & Length & $\begin{array}{l}\text { Circumference- } \\
\text { breadth }\end{array}$ & Instep height & Heel height & $\begin{array}{l}\text { Medial- } \\
\text { Lateral ball }\end{array}$ \\
\hline Eigenvalue & 5.71 & 4.56 & 2.25 & 1.66 & 1.40 \\
\hline Variance $(\%)$ & 30.07 & 23.98 & 11.84 & 8.75 & 7.37 \\
\hline Accumulative variance (\%) & 30.07 & 54.05 & 65.89 & 74.65 & 82.02 \\
\hline
\end{tabular}


고, 전체변량의 $23.98 \%$ 를 설명한다. 볼둘레 $(0.92)$, 볼 거리(0.90), 발너비(0.87), 발등둘레(0.84)의 높은 적 재값을 가지며, 발둘레와 너비에 영향을 미치는 요 인으로 해석되어 둘레너비 요인으로 명명하였다. 요 인 3 은 고유치가 2.25 이고, 전체변량의 $11.84 \%$ 를 설 명한다. 발등높이(0.89), 볼높이(0.75), 가쪽복사뼈높 이(0.71)의 높은 적재값을 가지며, 발등높이에 관여 하는 요인으로 해석된다. 요인 4는 고유치가 1.66 이 고, 전체변량의 $8.75 \%$ 를 설명한다. 발꿈치위점높이 (0.68), 발꿈치점높이 $(0.64)$, 발중심점상측길이 $(0.60)$ 의 높은 적재값을 가지며, 발꿈치높이에 영향을 미 치는 요인으로 해석된다. 요인 4의 항목 중 발중심 점상측길이는 유의성이 낮아 요인 2에도 요인부하 량이 분산되어 있는 것을 알 수 있다. 요인 5 는 고유 치가 1.40 이고, 전체변량의 $7.37 \%$ 를 설명하고, 내측 볼너비 $(0.87)$ 와 외측볼너비 $(-0.78)$ 의 높은 적재값 을 가지며, 발중심선을 기준으로 발가락의 내측과 외측 형태에 관여하는 요인으로 해석된다. 요인 5에 서 외측볼너비는 음의 값으로 요인 5의 점수가 클수 록 이 요인들의 값은 작아짐을 알 수 있고, 유의성이 낮아 요인 2에도 요인부하량이 분산되어 있는 것을 알 수 있었다.

\section{Classification of young men's foot shape}

발 형태를 유형별로 분류하기 위하여 요인분석 결 과, 추출된 각 요인을 독립변수로 군집분석을 실시
하였다. 군집의 수는 유형별 출현율을 고려하고, 군 집간 발 형태의 특징이 뚜렷이 나타나는 군집수를 고려하여 3 개의 유형으로 분류하였다. 유형 1 에 118 명(27.1\%), 유형 2에 166명(38.2\%), 유형 3에 151명 (34.7\%)의 분포를 나타내었다. 분류된 유형별로 발 형태의 특징을 살펴보기 위하여 요인점수와 발계측 치수에 대하여 분산분석을 실시하고, 사후검정으로 Duncan test로 분석하였다.

〈Table 3〉은 청년층 남성 발 형태 유형별 요인점 수에 대한 분산분석과 사후검정 결과를 나타낸다. 유형 1 은 대부분의 요인 값이 다른 유형에 비해 낮 게 나타났으며, 유형 2와 유형 3 은 요인 값이 높은 값과 중간 값을 함께 보여주었다. 유형 2는 둘레너 비, 발등높이, 발꿈치높이의 요인 값이 높게 나타났 으며, 유형 3 은 길이, 발꿈치높이, 발가락내측외측 의 요인 값이 높게 나타났다.

각 유형의 특징을 구체적으로 살펴보기 위해 발 계측 항목별 분산분석과 사후검정 결과는〈Table 4〉 와 같다. 유형 $1(n=118)$ 은 발중심점하측길이, 발꿈 치-발가쪽점길이, 발꿈치-발안쪽점길이, 발길이, 발 꿈치엄지발가락길이, 발꿈치-발등길이 등의 길이 항 목과 볼둘레, 볼거리, 발너비, 발등둘레 등의 둘레너 비 항목의 실측치 평균이 가장 낮게 나타났다. 또한 발등높이, 볼높이 등의 발등높이 항목과 발꿈치위점 높이, 발꿈치점높이 등의 발꿈치높이 항목들도 가장 낮은 값을 나타내었다. 발가락내측외측 항목에서 내

〈Table 3〉 Results of ANOVAs and posteriori tests of factor scores by foot shape type of young men

\begin{tabular}{|c|c|c|c|c|}
\hline Factors $\quad$ Types & $\begin{array}{l}\text { Type } 1 \\
(n=118)\end{array}$ & $\begin{array}{l}\text { Type } 2 \\
(n=166)\end{array}$ & $\begin{array}{l}\text { Type } 3 \\
(n=151)\end{array}$ & $F$-value \\
\hline $\begin{array}{l}\text { Factor } 1 \\
\text { Length }\end{array}$ & $\begin{array}{c}-0.706 \\
\mathrm{C}\end{array}$ & $\begin{array}{c}-0.224 \\
\text { B }\end{array}$ & $\begin{array}{l}0.798 \\
\mathrm{~A}\end{array}$ & $130.292^{* * *}$ \\
\hline $\begin{array}{c}\text { Factor } 2 \\
\text { Circumference-breadth }\end{array}$ & $\begin{array}{c}-0.424 \\
\mathrm{C}\end{array}$ & $\begin{array}{l}0.374 \\
\mathrm{~A}\end{array}$ & $\begin{array}{c}-0.080 \\
\mathrm{~B}\end{array}$ & $25.265^{* * *}$ \\
\hline $\begin{array}{c}\text { Factor } 3 \\
\text { Instep height }\end{array}$ & $\begin{array}{c}-0.520 \\
\mathrm{C}\end{array}$ & $\begin{array}{l}0.378 \\
\text { A }\end{array}$ & $\begin{array}{c}-0.010 \\
\mathrm{~B}\end{array}$ & $31.748^{* * *}$ \\
\hline $\begin{array}{c}\text { Factor } 4 \\
\text { Heel height }\end{array}$ & $\begin{array}{c}-0.526 \\
\text { B }\end{array}$ & $\begin{array}{l}0.200 \\
\text { A }\end{array}$ & $\begin{array}{l}0.191 \\
\text { A }\end{array}$ & $24.831^{* * *}$ \\
\hline $\begin{array}{c}\text { Factor } 5 \\
\text { Medial-lateral ball }\end{array}$ & $\begin{array}{l}0.234 \\
\mathrm{~B}\end{array}$ & $\begin{array}{c}-0.599 \\
\mathrm{C}\end{array}$ & $\begin{array}{l}0.476 \\
\mathrm{~A}\end{array}$ & $64.918^{* * *}$ \\
\hline
\end{tabular}

Duncan test: $\mathrm{A}>\mathrm{B}>\mathrm{C}$

${ }^{* * *} p<.001, \stackrel{* *}{p}<.01, \stackrel{*}{p}<<.05$ 
측볼너비는 중간 값을 나타내었고, 외측볼너비는 낮 은 값을 나타내었다. 즉, 유형 1은 발길이가 짧고, 발 둘레너비가 작고, 발등높이와 발꿈치 높이가 낮은
발 형태를 지닌 유형으로 나타났다.

유형 2(n=166)는 발중심점하측길이, 발꿈치-발가 쪽점길이, 발꿈치-발안쪽점길이, 발길이, 발꿈치엄지발

$\langle$ Table 4〉 Results of ANOVAs and posteriori tests of measured foot dimensions by foot shape type of young men

\begin{tabular}{|c|c|c|c|c|c|}
\hline & Items $\quad$ Types & $\begin{array}{l}\text { Type } 1 \\
(n=118)\end{array}$ & $\begin{array}{l}\text { Type } 2 \\
(n=166)\end{array}$ & $\begin{array}{l}\text { Type } 3 \\
(n=151)\end{array}$ & $F$-value \\
\hline \multirow{7}{*}{$\begin{array}{l}\text { Factor } 1 \\
\text { Length }\end{array}$} & 17 Ball center-to-heel length & $\begin{array}{c}166.82 \\
\mathrm{C}\end{array}$ & $\begin{array}{c}173.65 \\
\text { B }\end{array}$ & $\begin{array}{c}181.11 \\
\mathrm{~A}\end{array}$ & $127.94^{* * *}$ \\
\hline & 15 Lateral ball length & $\begin{array}{c}153.79 \\
\text { C }\end{array}$ & $\begin{array}{c}158.88 \\
\text { B }\end{array}$ & $\begin{array}{c}168.15 \\
\text { A }\end{array}$ & $108.20^{* * *}$ \\
\hline & 14 Medial ball length & $\begin{array}{l}177.77 \\
\mathrm{C}\end{array}$ & $\begin{array}{c}184.48 \\
\text { B }\end{array}$ & $\begin{array}{c}192.51 \\
\text { A }\end{array}$ & $115.83^{* * *}$ \\
\hline & 1 Foot length & $\begin{array}{c}245.48 \\
\text { C }\end{array}$ & $\begin{array}{c}255.68 \\
\text { B }\end{array}$ & $\begin{array}{c}265.53 \\
\text { A }\end{array}$ & $162.97^{* * *}$ \\
\hline & 2 Heel-to-toe 1 length & $\begin{array}{c}245.23 \\
\text { C }\end{array}$ & $\begin{array}{c}255.23 \\
\text { B }\end{array}$ & $\begin{array}{c}265.31 \\
\text { A }\end{array}$ & $160.76^{* * *}$ \\
\hline & 3 Heel-to-instep length & $\begin{array}{c}144.84 \\
\mathrm{C}\end{array}$ & $\begin{array}{c}151.22 \\
\mathrm{~B}\end{array}$ & $\begin{array}{c}157.54 \\
\mathrm{~A}\end{array}$ & $101.55^{* * *}$ \\
\hline & 13 Heel-to-instep circumference & $\begin{array}{c}368.35 \\
\mathrm{C}\end{array}$ & $\begin{array}{c}385.55 \\
\text { B }\end{array}$ & $\begin{array}{c}395.37 \\
\text { A }\end{array}$ & $112.24^{* * *}$ \\
\hline \multirow{4}{*}{$\begin{array}{c}\text { Factor } 2 \\
\text { Circumference- } \\
\text { breadth }\end{array}$} & 11 Ball circumference & $\begin{array}{c}247.94 \\
\text { C }\end{array}$ & $\begin{array}{c}261.74 \\
\text { A }\end{array}$ & $\begin{array}{c}258.43 \\
\text { B }\end{array}$ & $66.17^{* * *}$ \\
\hline & 5 Ball distance & $\begin{array}{c}101.39 \\
\mathrm{~B}\end{array}$ & $\begin{array}{c}106.47 \\
\mathrm{~A}\end{array}$ & $\begin{array}{c}106.06 \\
\mathrm{~A}\end{array}$ & $48.91^{* * *}$ \\
\hline & 4 Foot breadth & $\begin{array}{c}98.33 \\
\mathrm{~B}\end{array}$ & $\begin{array}{c}103.07 \\
\mathrm{~A}\end{array}$ & $\begin{array}{c}103.00 \\
\mathrm{~A}\end{array}$ & $51.22^{* * *}$ \\
\hline & 12 Instep circumference & $\begin{array}{c}247.85 \\
\mathrm{C}\end{array}$ & $\begin{array}{c}261.64 \\
\text { A }\end{array}$ & $\begin{array}{c}258.29 \\
\text { B }\end{array}$ & $70.19^{* * *}$ \\
\hline \multirow{3}{*}{$\begin{array}{c}\text { Factor } 3 \\
\text { Instep height }\end{array}$} & 7 Instep height & $\begin{array}{c}56.86 \\
\mathrm{C}\end{array}$ & $\begin{array}{c}61.59 \\
\text { A }\end{array}$ & $\begin{array}{c}58.92 \\
\text { B }\end{array}$ & $45.61^{* * *}$ \\
\hline & 6 Ball height & $\begin{array}{c}36.02 \\
\mathrm{C}\end{array}$ & $\begin{array}{c}38.43 \\
\mathrm{~A}\end{array}$ & $\begin{array}{c}37.34 \\
\mathrm{~B}\end{array}$ & $36.26^{* * *}$ \\
\hline & 8 Lateral malleolus height & $\begin{array}{c}69.70 \\
\text { B }\end{array}$ & $\begin{array}{c}74.13 \\
\mathrm{~A}\end{array}$ & $\begin{array}{c}73.89 \\
\text { A }\end{array}$ & $40.71^{* * *}$ \\
\hline \multirow{3}{*}{$\begin{array}{c}\text { Factor } 4 \\
\text { Heel height }\end{array}$} & 10 Height of upper point of heel point & $\begin{array}{c}57.51 \\
\mathrm{~B}\end{array}$ & $\begin{array}{c}61.83 \\
\mathrm{~A}\end{array}$ & $\begin{array}{c}62.66 \\
\mathrm{~A}\end{array}$ & $27.57^{* * *}$ \\
\hline & 9 Heel height & $\begin{array}{c}20.41 \\
\mathrm{~B}\end{array}$ & $\begin{array}{c}22.67 \\
\mathrm{~A}\end{array}$ & $\begin{array}{c}22.55 \\
\text { A }\end{array}$ & $26.65^{* * *}$ \\
\hline & 16 Ball center-to-toe 2 length & $\begin{array}{c}74.53 \\
\text { B }\end{array}$ & $\begin{array}{c}79.25 \\
\text { A }\end{array}$ & $\begin{array}{c}79.68 \\
\text { A }\end{array}$ & $34.57^{* * *}$ \\
\hline \multirow{2}{*}{$\begin{array}{c}\text { Factor } 5 \\
\text { Medial-lateral ball }\end{array}$} & 18 Medial ball width & $\begin{array}{c}44.86 \\
\text { B }\end{array}$ & $\begin{array}{c}43.63 \\
\mathrm{C}\end{array}$ & $\begin{array}{c}48.19 \\
\mathrm{~A}\end{array}$ & $60.08^{* * *}$ \\
\hline & 19 Lateral ball width & $\begin{array}{c}53.47 \\
\mathrm{C}\end{array}$ & $\begin{array}{c}59.44 \\
\text { A }\end{array}$ & $\begin{array}{c}54.82 \\
\text { B }\end{array}$ & $104.57^{* * *}$ \\
\hline
\end{tabular}

Duncan test: $\mathrm{A}>\mathrm{B}>\mathrm{C}$

${ }^{* * *} p<.001, \stackrel{* *}{p}<.01,{ }^{*} p<.05$ 
가락길이, 발꿈치-발등길이 등의 길이 항목에서 실측 치 평균이 중간으로 나타났고, 볼둘레, 볼거리, 발너 비, 발등둘레 등의 둘레너비 항목과 발등높이, 볼높이 등의 발등높이 항목의 실측치 평균이 가장 높게 나타 났다. 또한 발꿈치위점높이, 발꿈치점높이 등의 발꿈 치높이 항목들도 높은 값을 나타내었다. 발가락내측 외측 항목에서 내측볼너비는 낮은 값을 나타내었고, 외측볼너비는 높은 값을 나타내었다. 즉, 유형 2는 발 길이는 보통이고, 발둘레너비가 크고, 발등높이와 발 꿈치 높이가 높은 발 형태를 지닌 유형으로 나타났다.

유형 3(n=151)은 발중심점하측길이, 발꿈치-발가 쪽점길이, 발꿈치-발안쪽점길이, 발길이, 발꿈치엄지 발가락길이, 발꿈치-발등길이 등의 길이 항목에서 실 측치 평균이 가장 높게 나타났다. 볼거리와 발너비의 너비항목에서 높은 값을 볼둘레와 발등둘레의 둘레 항목과 발등높이, 볼높이 등의 발등높이 항목에서 중 간 값을 나타내었고, 발가락내측외측 항목에서 내측 볼너비는 높은 값을 나타내었고, 외측볼너비는 중간 값을 나타내었다. 유형 2와 더불어 발꿈치위점높이, 발꿈치점높이 등의 발꿈치높이 항목이 높은 값을 나 타내었다. 즉, 유형 3 은 발길이가 길고 발너비가 넓고 발둘레와 발등높이가 중간이 편에 속하며, 발꿈치높 이가 높은 발 형태를 지닌 유형으로 나타났다.

\section{Factors of middle-aged elderly men's foot} shape

중노년층(40 69세) 남성 발 형태의 구성요인을 도출하기 위하여 요인분석을 실시하였다. 베리맥스 (Varimax) 방법으로 직교회전을 하여 고유치가 1 이 상인 것으로 요인 수는 최종 6 개의 요인이 추출되었 다. 〈Table 5〉는 중노년층 남성의 발 계측치수에 대 한 요인분석의 결과를 보여주며, 6 개의 요인이 설명 할 수 있는 분산은 전체의 $79.06 \%$ 이다.

요인 1 은 고유치가 4.72 이고, 전체변량의 $24.87 \%$ 를 설명한다. 발직선길이 $(0.87)$, 발꿈치엄지발가락 길이 $(0.86)$, 발꿈치-발등길이 $(0.84)$, 발꿈치-발안쪽점 길이 $(0.80)$, 발꿈치-발가쪽점길이 $(0.78)$, 발꿈치-발등 둘레 $(0.70)$ 의 높은 적재값을 가지며, 발길이에 영향 을 미치는 요인으로 해석하여 길이요인으로 명명하였 다. 요인 2는 고유치가 3.14 이고, 전체변량의 $16.54 \%$ 를 설명한다. 볼거리(0.92), 발너비(0.87), 발등둘레
(0.59), 볼둘레 $(0.58)$ 의 높은 적재값을 가지며, 발둘 레와 너비에 영향을 미치는 요인으로 해석되어 둘레 너비 요인으로 명명하였다. 요인 3은 고유치가 2.06 이고, 전체변량의 $10.84 \%$ 를 설명한다. 발등높이 $(0.86)$, 볼높이(0.75)의 높은 적재값을 가지며, 발등높이에 관 영하는 요인으로 해석된다. 요인 4는 고유치가 1.89 이 고, 전체변량의 $9.96 \%$ 를 설명한다. 발꿈치위점높이 (0.74), 발꿈치점높이 $(0.73)$ 등의 높은 적재값을 가 지며, 발꿈치높이에 영향을 미치는 요인으로 해석된 다. 요인 5 는 고유치가 1.81 이고, 전체변량의 $9.53 \%$ 를 설명한다. 발중심점상측길이( 0.86$)$, 발중심점하 측길이 $(-0.76)$ 의 높은 적재값을 가지며, 발중심점을 기준으로 발가락길이와 발중심점에서 발꿈치까지 의 길이에 영향을 미치는 요인으로 해석되어 발중 심점요인으로 명명하였다. 요인 5의 항목 중 발중심 점하측길이는 유의성이 낮아 요인 1 에도 요인부하 량이 분산되어 있는 것을 알 수 있다. 요인 6 은 고유 치가 1.39 이고, 전체변량의 $7.32 \%$ 를 설명하고, 외측 볼너비 $(0.86)$ 와 내측볼너비 $(-0.68)$ 의 높은 적재값 을 가지며, 발중심선을 기준으로 발가락의 내측과 외측 형태에 관여하는 요인으로 해석된다. 요인 6에 서 내측볼너비는 음의 값으로 요인 6 의 점수가 클수 록 이 요인들의 값은 작아짐을 알 수 있고, 유의성이 낮아 요인 2에도 요인부하량이 분산되어 있는 것을 알 수 있었다.

\section{Classification of middle-aged elderly men's foot shape}

발 형태를 유형별로 분류하기 위하여 요인분석 결과, 추출된 각 요인을 독립변수로 군집분석을 실 시하였다. 군집의 수는 유형별 출현율을 고려하고, 군집간 발 형태의 특징이 뚜렷이 나타나는 군집수 를 고려하여 4개의 유형으로 분류하였다. 유형 1에 228 명(39.0\%), 유형 2에 51명(8.7\%), 유형 3에 149 명 $(25.5 \%)$, 유형 4 에 157 명(26.8\%)의 분포를 나타내 었다. 분류된 유형별로 발 형태의 특징을 살펴보기 위하여 요인점수와 발계측치수에 대하여 분산분석을 실시하고, 사후검정으로 Duncan test로 분석하였다.

〈Table 6〉은 중노년층 남성 발 형태 유형별 요인 점수에 대한 분산분석과 사후검정 결과를 나타낸다. 유형 1 은 길이항목, 발등높이항목, 발꿈치높이항목, 
$\langle$ Table 5〉 Results of the factor analyses of measured feet dimensions of middle-aged elderly men

\begin{tabular}{|c|c|c|c|c|c|c|}
\hline Items $\quad$ Factor & 1 & 2 & 3 & 4 & 5 & 6 \\
\hline 1 Foot length & 0.87 & 0.28 & 0.22 & 0.17 & -0.05 & -0.07 \\
\hline 2 Heel-to-toe 1 length & 0.86 & 0.28 & 0.22 & 0.16 & -0.06 & -0.08 \\
\hline 3 Heel-to-instep length & 0.84 & 0.17 & -0.25 & 0.02 & 0.14 & 0.15 \\
\hline 14 Medial ball length & 0.80 & 0.27 & 0.00 & 0.25 & -0.19 & -0.10 \\
\hline 15 Lateral ball length & 0.78 & -0.02 & 0.15 & 0.31 & -0.25 & 0.00 \\
\hline 13 Heel-to-instep circumference & 0.70 & 0.17 & -0.08 & -0.16 & 0.23 & 0.14 \\
\hline 5 Ball distance & 0.24 & 0.92 & 0.02 & 0.20 & 0.03 & 0.12 \\
\hline 4 Foot breadth & 0.26 & 0.87 & 0.08 & 0.26 & -0.02 & 0.17 \\
\hline 12 Instep circumference & 0.19 & 0.59 & 0.51 & -0.04 & -0.01 & 0.07 \\
\hline 11 Ball circumference & 0.16 & 0.58 & 0.17 & -0.19 & 0.20 & -0.09 \\
\hline 7 Instep height & -0.15 & 0.11 & 0.86 & 0.26 & -0.13 & 0.06 \\
\hline 6 Ball height & 0.14 & 0.12 & 0.75 & -0.23 & 0.25 & 0.15 \\
\hline 10 Height of upper point of heel point & 0.13 & 0.08 & -0.07 & 0.74 & 0.43 & 0.02 \\
\hline 9 Heel height & 0.12 & 0.10 & 0.03 & 0.73 & -0.01 & 0.00 \\
\hline 8 Lateral malleolus height & 0.31 & 0.03 & 0.42 & 0.47 & 0.10 & 0.17 \\
\hline 16 Ball center-to-toe 2 length & 0.05 & 0.16 & 0.12 & 0.22 & 0.86 & -0.06 \\
\hline 17 Ball center-to-heel length & 0.61 & 0.07 & 0.04 & -0.03 & -0.76 & 0.02 \\
\hline 19 Lateral ball width & 0.11 & 0.36 & 0.21 & 0.16 & -0.06 & 0.86 \\
\hline 18 Medial ball width & 0.18 & 0.61 & -0.13 & 0.14 & 0.05 & -0.68 \\
\hline Factor character & Length & $\begin{array}{c}\text { Circumference- } \\
\text { breadth }\end{array}$ & $\begin{array}{l}\text { Instep } \\
\text { height }\end{array}$ & $\begin{array}{l}\text { Heel } \\
\text { height }\end{array}$ & $\begin{array}{c}\text { Ball } \\
\text { center }\end{array}$ & $\begin{array}{l}\text { Medial- } \\
\text { lateral ball }\end{array}$ \\
\hline Eigenvalue & 4.72 & 3.14 & 2.06 & 1.89 & 1.81 & 1.39 \\
\hline Variance $(\%)$ & 24.87 & 16.54 & 10.84 & 9.96 & 9.53 & 7.32 \\
\hline Accumulative variance $(\%)$ & 24.87 & 41.41 & 52.25 & 62.21 & 71.74 & 79.06 \\
\hline
\end{tabular}

발중심점항목의 요인 값이 비교적 낮은 값을 나타 내었고, 둘레너비항목과 발가락내측외측항목의 경 우에 비교적 높은 값을 나타내었다. 유형 2는 길이 항목, 둘레너비항목에서 중간 값을 나타내었고, 발 등높이는 비교적 낮은 값을 나타내었다. 반면에 발꿈 치높이항목, 발중심점항목, 발가락내측외측항목에서 높은 값을 나타내었다. 유형 3은 길이항목과 발중심 점항목에서 중간 값을 나타내었고, 둘레너비항목과 발꿈치높이항목에서 낮은 값을 나타내었다. 반면에 발등높이항목과 발가락내측외측항목에서 높은 값 을 나타내었다. 유형 4는 길이항목과 둘레너비항목 에서 높은 값을 나타내었고, 발등높이, 발꿈치높이항 목, 발가락내측외측항목에서 중간 값을 나타내었다.
반면에 발중심점항목에서 낮은 값을 나타내었다.

각 유형의 특징을 구체적으로 살펴보기 위해 발 계측 항목별 분산분석과 사후검정 결과는 〈Table 7〉 과 같다. 유형 $1(n=228)$ 은 발직선길이, 발꿈치엄지 발가락길이, 발꿈치-발등길이, 발꿈치-발안쪽점길이, 발꿈치-발가쪽점길이 등의 길이 항목과 발꿈치위점 높이, 발꿈치점높이 등의 발꿈치높이 항목의 실측치 평균이 가장 낮게 나타났다. 볼거리, 볼둘레, 발등둘 레, 발너비의 둘레너비 항목의 실측치 평균이 높은 값을 나타내었고, 볼높이항목은 중간 값을 나타내었 다. 발중심점항목에서는 발중심점상측길이는 낮은 값으로 발중심점하측길이는 중간 값으로 나타났으 며, 발가락내측외측항목에서 외측볼너비는 높은 값 
〈Table 6〉 Results of ANOVAs and posteriori tests of factor scores by foot shape type of middle-aged elderly men

\begin{tabular}{|c|c|c|c|c|c|}
\hline Factors $\quad$ Types & $\begin{array}{l}\text { Type } 1 \\
(n=228)\end{array}$ & $\begin{array}{l}\text { Type } 2 \\
(n=51)\end{array}$ & $\begin{array}{l}\text { Type } 3 \\
(n=149)\end{array}$ & $\begin{array}{l}\text { Type } 4 \\
(n=157)\end{array}$ & $F$-value \\
\hline $\begin{array}{l}\text { Factor } 1 \\
\text { Length }\end{array}$ & $\begin{array}{c}-0.506 \\
\mathrm{C}\end{array}$ & $\begin{array}{c}0.034 \\
\mathrm{~B}\end{array}$ & $\begin{array}{c}0.183 \\
\mathrm{~B}\end{array}$ & $\begin{array}{c}0.552 \\
\mathrm{~A}\end{array}$ & $45.316^{* * *}$ \\
\hline $\begin{array}{c}\text { Factor } 2 \\
\text { Circumference-breadth }\end{array}$ & $\begin{array}{c}0.358 \\
\mathrm{~A}\end{array}$ & $\begin{array}{c}-0.334 \\
\mathrm{~B}\end{array}$ & $\begin{array}{c}-0.757 \\
C\end{array}$ & $\begin{array}{c}0.303 \\
\mathrm{~A}\end{array}$ & $57.512^{* * *}$ \\
\hline $\begin{array}{c}\text { Factor } 3 \\
\text { Instep height }\end{array}$ & $\begin{array}{c}-0.242 \\
\mathrm{C}\end{array}$ & $\begin{array}{c}-0.383 \\
\mathrm{C}\end{array}$ & $\begin{array}{c}0.450 \\
\mathrm{~A}\end{array}$ & $\begin{array}{c}0.082 \\
\mathrm{~B}\end{array}$ & $18.916^{* * *}$ \\
\hline $\begin{array}{c}\text { Factor } 4 \\
\text { Heel height }\end{array}$ & $\begin{array}{c}-0.224 \\
\mathrm{C}\end{array}$ & $\begin{array}{c}1.952 \\
\mathrm{~A}\end{array}$ & $\begin{array}{c}-0.544 \\
\mathrm{D}\end{array}$ & $\begin{array}{c}0.120 \\
\mathrm{~B}\end{array}$ & $152.383^{* * *}$ \\
\hline $\begin{array}{l}\text { Factor } 5 \\
\text { Ball center }\end{array}$ & $\begin{array}{c}-0.173 \\
\mathrm{C}\end{array}$ & $\begin{array}{c}1.253 \\
\mathrm{~A}\end{array}$ & $\begin{array}{c}0.396 \\
\mathrm{~B}\end{array}$ & $\begin{array}{c}-0.542 \\
\mathrm{D}\end{array}$ & $72.240^{* * *}$ \\
\hline $\begin{array}{c}\text { Factor } 6 \\
\text { Medial-lateral ball }\end{array}$ & $\begin{array}{c}0.278 \\
\mathrm{~A}\end{array}$ & $\begin{array}{c}0.194 \\
\text { A }\end{array}$ & $\begin{array}{c}0.210 \\
\mathrm{~A}\end{array}$ & $\begin{array}{c}-0.689 \\
\text { B }\end{array}$ & $40.197^{* * *}$ \\
\hline
\end{tabular}

Duncan test: $\mathrm{A}>\mathrm{B}>\mathrm{C}$

${ }^{* * *} p<.001, \stackrel{* *}{p}<.01, \stackrel{*}{p}<.05$

으로 내측볼너비는 중간 값으로 나타났다. 즉, 유형 1은 발길이가 짧고, 발둘레너비가 크고, 볼높이가 중간인 편에 속하고, 발꿈치높이가 낮은 발 형태를 지닌 유형으로 나타났다.

유형 $2(n=51)$ 는 발직선길이, 발꿈치엄지발가락길 이, 발꿈치-발등길이, 발꿈치-발안쪽점길이, 발꿈치발가쪽점길이 등의 길이 항목에서 실측치 평균이 중간으로 나타났다. 볼거리와 발너비의 너비항목에 서 높은 값을 나타내었고, 발등둘레와 볼둘레의 둘 레항목와 볼높이항목은 낮은 값을 나타내었다. 또한 발꿈치위점높이, 발꿈치점높이 등의 발꿈치높이 항 목들도 가장 높은 값을 나타내었다. 발중심점항목에 서는 발중심점상측길이는 높은 값으로 발중심점하 측길이는 낮은 값으로 나타났으며, 발가락내측외측 항목에서 외측볼너비는 높은 값으로 내측볼너비는 중간 값으로 나타났다. 즉, 유형 2 는 발길이가 보통 이고, 발너비는 넓고, 발둘레와 볼높이가 낮은 타원 형의 편평률을 가진 납작한 형태이며, 발꿈치높이가 가장 높은 발 형태를 지닌 유형으로 나타났다.

유형 3(n=149)은 발직선길이, 발꿈치엄지발가락 길이, 발꿈치-발등길이의 길이항목에서 실측치 평 균이 중간 값을 나타내었고, 발꿈치-발안쪽점길이와 발꿈치-발가쪽점길이의 길이 항목에서 낮은 값을 나타내었다. 볼거리와 발너비의 너비항목에서 낮은
값을 나타내었고, 발등둘레와 볼둘레의 둘레항목에 서 중간 값을 나타내었다. 볼높이항목에서 높은 값 을 나타내었으며, 발꿈치위점높이, 발꿈치점높이 등 의 발꿈치높이 항목의 실측치 평균이 낮게 나타났 다. 발중심점항목에서는 발중심점상측길이와 발중 심점하측길이는 중간 값으로 나타났으며, 발가락내 측외측항목에서 외측볼너비는 중간 값으로, 내측볼 너비는 낮은 값으로 나타났다. 즉, 유형 3 는 발길이와 발둘레는 보통이고, 발너비는 작고, 볼높이는 높은 편에 속하는 편평률이 큰 둥근 형태이며, 발꿈치높 이가 가장 낮은 발 형태를 지닌 유형으로 나타났다.

유형 4(n=157)은 발직선길이, 발꿈치엄지발가락 길이, 발꿈치-발등길이, 발꿈치-발안쪽점길이, 발꿈 치-발가쪽점길이 등의 길이항목와 볼거리, 볼둘레, 발등둘레, 발너비의 너비항목에서 실측치 평균이 가 장 높은 것으로 나타났으며, 볼높이항목과 발꿈치위 점높이, 발꿈치점높이 등의 발꿈치높이 항목의 실측 치 평균이 중간 값을 나타내었다. 발중심점항목에서 는 발중심점상측길이는 낮은 값으로, 발중심점하측 길이는 높은 값으로 나타났으며, 발가락내측외측항 목에서 외측볼너비는 낮은 값으로, 내측볼너비는 높 은 값으로 나타났다. 즉, 유형 4는 발길이가 길고, 발둘레너비가 크고, 볼높이와 발꿈치높이는 중간인 편에 속하는 발 형태를 지닌 유형으로 나타났다. 
〈Table 7〉 Results of ANOVAs and posteriori tests of measured foot dimensions by foot shape type of middle-aged elderly men

\begin{tabular}{|c|c|c|c|c|c|c|}
\hline & Items & $\begin{array}{l}\text { Type } 1 \\
(n=228)\end{array}$ & $\begin{array}{l}\text { Type } 2 \\
(n=51)\end{array}$ & $\begin{array}{l}\text { Type } 3 \\
(n=149)\end{array}$ & $\begin{array}{l}\text { Type } 4 \\
(n=157)\end{array}$ & $F$-value \\
\hline \multirow{6}{*}{$\begin{array}{l}\text { Factor } 1 \\
\text { Length }\end{array}$} & 1 Foot length & $\begin{array}{c}240.44 \\
\mathrm{C}\end{array}$ & $\begin{array}{c}245.75 \\
\text { B }\end{array}$ & $\begin{array}{c}244.19 \\
\text { B }\end{array}$ & $\begin{array}{c}251.90 \\
\mathrm{~A}\end{array}$ & $47.12^{* * *}$ \\
\hline & 2 Heel-to-toe 1 length & $\begin{array}{c}240.06 \\
\mathrm{C}\end{array}$ & $\begin{array}{c}245.04 \\
\text { B }\end{array}$ & $\begin{array}{c}243.70 \\
\text { B }\end{array}$ & $\begin{array}{c}251.40 \\
\mathrm{~A}\end{array}$ & $46.87^{* * *}$ \\
\hline & 3 Heel-to-instep length & $\begin{array}{c}130.31 \\
\mathrm{C}\end{array}$ & $\begin{array}{c}135.61 \\
\mathrm{AB}\end{array}$ & $\begin{array}{c}133.25 \\
\text { B }\end{array}$ & $\begin{array}{c}136.09 \\
\text { A }\end{array}$ & $14.65^{* * *}$ \\
\hline & 14 Medial ball length & $\begin{array}{c}175.36 \\
\mathrm{C}\end{array}$ & $\begin{array}{c}180.92 \\
\text { B }\end{array}$ & $\begin{array}{c}175.72 \\
\mathrm{C}\end{array}$ & $\begin{array}{c}184.52 \\
\text { A }\end{array}$ & $49.01^{* * *}$ \\
\hline & 15 Lateral ball length & $\begin{array}{c}150.83 \\
\mathrm{D}\end{array}$ & $\begin{array}{c}157.76 \\
\text { B }\end{array}$ & $\begin{array}{c}154.64 \\
\mathrm{C}\end{array}$ & $\begin{array}{c}160.40 \\
\text { A }\end{array}$ & $44.47^{* * *}$ \\
\hline & 13 Heel-to-instep circumference & $\begin{array}{c}363.85 \\
\mathrm{~B}\end{array}$ & $\begin{array}{c}370.47 \\
\mathrm{~A}\end{array}$ & $\begin{array}{c}373.69 \\
\text { A }\end{array}$ & $\begin{array}{c}376.67 \\
\text { A }\end{array}$ & $10.15^{* * *}$ \\
\hline \multirow{4}{*}{$\begin{array}{c}\text { Factor } 2 \\
\text { Circumference- } \\
\text { breadth }\end{array}$} & 5 Ball distance & $\begin{array}{c}99.45 \\
\mathrm{~A}\end{array}$ & $\begin{array}{c}99.20 \\
\mathrm{~A}\end{array}$ & $\begin{array}{c}94.76 \\
\text { B }\end{array}$ & $\begin{array}{c}100.20 \\
\text { A }\end{array}$ & $41.32^{* * *}$ \\
\hline & 4 Foot breadth & $\begin{array}{c}96.13 \\
\mathrm{~A}\end{array}$ & $\begin{array}{c}96.3 \\
\mathrm{~A}\end{array}$ & $\begin{array}{c}92.06 \\
\mathrm{~B}\end{array}$ & $\begin{array}{c}97.06 \\
\mathrm{~A}\end{array}$ & $37.03^{* * *}$ \\
\hline & 12 Instep circumference & $\begin{array}{c}253.13 \\
\mathrm{AB}\end{array}$ & $\begin{array}{c}246.92 \\
\text { C }\end{array}$ & $\begin{array}{c}249.39 \\
\mathrm{BC}\end{array}$ & $\begin{array}{c}256.18 \\
\mathrm{~A}\end{array}$ & $8.60^{* * *}$ \\
\hline & 11 Ball circumference & $\begin{array}{c}256.50 \\
\mathrm{AB}\end{array}$ & $\begin{array}{c}246.82 \\
\mathrm{C}\end{array}$ & $\begin{array}{c}253.18 \\
\text { B }\end{array}$ & $\begin{array}{c}259.83 \\
\mathrm{~A}\end{array}$ & $5.60^{* *}$ \\
\hline \multirow{2}{*}{$\begin{array}{c}\text { Factor } 3 \\
\text { Instep height }\end{array}$} & 7 Instep height & $\begin{array}{c}60.86 \\
\mathrm{~A}\end{array}$ & $\begin{array}{c}62.10 \\
\mathrm{~A}\end{array}$ & $\begin{array}{c}61.91 \\
\mathrm{~A}\end{array}$ & $\begin{array}{c}62.03 \\
\mathrm{~A}\end{array}$ & 1.88 \\
\hline & 6 Ball height & $\begin{array}{c}36.45 \\
\text { B }\end{array}$ & $\begin{array}{c}35.25 \\
\mathrm{C}\end{array}$ & $\begin{array}{c}39.01 \\
\mathrm{~A}\end{array}$ & $\begin{array}{c}36.89 \\
\text { B }\end{array}$ & $29.44^{* * *}$ \\
\hline \multirow{3}{*}{$\begin{array}{c}\text { Factor } 4 \\
\text { Heel height }\end{array}$} & 10 Height of upper point of heel point & $\begin{array}{c}41.14 \\
\mathrm{C} \\
\end{array}$ & $\begin{array}{c}56.75 \\
\text { A } \\
\end{array}$ & $\begin{array}{c}40.73 \\
\mathrm{C} \\
\end{array}$ & $\begin{array}{c}42.32 \\
\mathrm{~B} \\
\end{array}$ & $199.91^{* * *}$ \\
\hline & 9 Heel height & $\begin{array}{c}24.87 \\
\mathrm{C}\end{array}$ & $\begin{array}{c}29.90 \\
\text { A }\end{array}$ & $\begin{array}{c}24.42 \\
\mathrm{C}\end{array}$ & $\begin{array}{c}26.76 \\
\text { B }\end{array}$ & $40.25^{* * *}$ \\
\hline & 8 Lateral malleolus height & $\begin{array}{c}66.82 \\
\mathrm{C}\end{array}$ & $\begin{array}{c}72.53 \\
\mathrm{~A}\end{array}$ & $\begin{array}{c}68.40 \\
\text { B }\end{array}$ & $\begin{array}{c}68.66 \\
\text { B }\end{array}$ & $22.61^{* * *}$ \\
\hline \multirow{2}{*}{$\begin{array}{l}\text { Factor } 5 \\
\text { Ball center }\end{array}$} & 16 Ball center-to-toe 2 length & $\begin{array}{c}68.69 \\
\mathrm{C} \\
\end{array}$ & $\begin{array}{c}86.14 \\
\text { A }\end{array}$ & $\begin{array}{c}72.34 \\
\text { B }\end{array}$ & $\begin{array}{c}67.13 \\
\mathrm{C} \\
\end{array}$ & $52.03^{* * *}$ \\
\hline & 17 Ball center-to-heel length & $\begin{array}{c}168.72 \\
\text { B }\end{array}$ & $\begin{array}{c}156.55 \\
\mathrm{C}\end{array}$ & $\begin{array}{c}168.03 \\
\text { B }\end{array}$ & $\begin{array}{c}181.43 \\
\text { A }\end{array}$ & $75.60^{* * *}$ \\
\hline \multirow{2}{*}{$\begin{array}{c}\text { Factor } 6 \\
\text { Medial- } \\
\text { lateral ball }\end{array}$} & 19 Lateral ball width & $\begin{array}{c}54.62 \\
\mathrm{~A}\end{array}$ & $\begin{array}{c}54.53 \\
\mathrm{~A}\end{array}$ & $\begin{array}{c}53.16 \\
\text { B }\end{array}$ & $\begin{array}{c}51.96 \\
\mathrm{C}\end{array}$ & $13.41^{* * *}$ \\
\hline & 18 Medial ball width & $\begin{array}{c}41.54 \\
\text { B }\end{array}$ & $\begin{array}{c}41.94 \\
\text { B }\end{array}$ & $\begin{array}{c}38.86 \\
\mathrm{C}\end{array}$ & $\begin{array}{c}45.10 \\
\mathrm{~A}\end{array}$ & $73.66^{* * *}$ \\
\hline
\end{tabular}

Duncan test: $\mathrm{A}>\mathrm{B}>\mathrm{C}$

${ }^{* * *} p<.001, \stackrel{* *}{p}<.01, \stackrel{*}{p}<.05$ 


\section{Conclusion}

본 연구는 20 39세 청년층과 40 69세 중노년층 남성을 대상으로 연령별 발계측 치수의 차이를 분 석하고, 발 형태를 유형별로 분류하고, 유형별 특징 을 분석함으로써 청년층과 중노년층 남성의 신발 제 작을 위한 기초자료를 제시하고자 하였다. 연구 결 과는 다음과 같다.

첫째, 청년층 남성 발계측항목에 대한 요인분석한 결과, 5 개 요인이 추출되었으며, 전체변량의 $82.02 \%$ 를 설명하였다. 길이, 둘레너비, 발등높이, 발꿈치높 이, 발가락내측외측의 5 개의 요인이었다.

둘째, 청년층 남성의 발 형태에 따른 유형별로 군 집분석한 결과, 3 개의 유형으로 분류되었으며, 유형 1 에 118명(27.1\%), 유형 2에 166명(38.2\%), 유형 3에 151 명(34.7\%)의 분포를 나타내었다. 유형 1은 작고 낮은 발형으로 발길이가 짧고, 발둘레너비가 작고, 발등높이와 발꿈치 높이가 낮은 편에 속하는 유형 이다. 유형 2 는 두툼한 발형으로 발길이는 보통이 고, 발둘레너비가 크고, 발등높이와 발꿈치 높이가 높은 편에 속하는 유형이다. 유형 3 은 길고 넓은 발 형으로 발길이가 길고, 발너비가 넓고, 발둘레와 발 등높이가 중간이 편에 속하며, 발꿈치높이가 높은 편에 속하는 유형이다.

셋째, 중노년층 남성 발계측항목에 대한 요인분석 한 결과, 6 개 요인이 추출되었으며, 전체변량의 $79.06 \%$ 를 설명하였다. 길이, 둘레너비, 발등높이, 발꿈치높 이, 발중심점, 발가락내측외측의 6 개의 요인이었다.

넷째, 중노년층 남성의 발 형태에 따른 유형별로 군집분석한 결과, 4 개의 유형으로 분류되었으며, 유 형 1에 228명(39.0\%), 유형 2에 51명(8.7\%), 유형 3 에 149 명 $(25.5 \%)$, 유형 4 에 157 명 $(26.8 \%)$ 의 분포를 나타내었다. 유형 1 은 작고 보통 발형으로 발길이가 짧고, 발둘레너비가 크고, 볼높이가 중간인 편에 속 하고, 발꿈치높이가 낮은 편에 속하는 유형이다. 유 형 2는 납작한 발형으로 발길이가 보통이고, 발너비 는 넓고, 발둘레와 볼높이가 낮은 타원형의 편평률 을 가진 납작한 형태이며, 발꿈치높이가 가장 높은 편에 속하는 유형이다. 유형 3 은 둥근 발형으로 발 길이와 발둘레는 보통이고, 발너비는 작고, 볼높이 는 높은 편에 속하는 편평률이 큰 둥근 형태이며, 발
꿈치높이가 가장 낮은 편에 속하는 유형이다. 유형 4는 길고 보통 발형으로 발길이가 길고, 발둘레너비 가 크고, 볼높이와 발꿈치높이는 중간인 편에 속하 는 유형이다.

이상과 같이, 청년층과 중노년층 남성의 발 형태 구성요인을 추출하여 비교한 결과, 길이, 둘레너비, 발등높이, 발꿈치높이, 발가락내측외측의 5 개의 요 인이 동일하게 나타났으며, 중노년층 남성에서 청년 층에 나타나지 않은 발중심점의 요인이 독립적으로 추출되었다. 청년층과 중노년층 남성의 발 형태를 비교한 결과, 중노년층 남성의 경우 볼높이가 낮은 납작한 발 형태가 적게 나타나는 경향을 보여주었 다. 또한 청년층과 중노년층 남성의 발 형태는 발길 이, 발둘레, 발너비의 항목 이외에도 발등높이 및 볼 높이 등의 요인에 따른 다양한 유형으로 분류되어 짐을 알 수 있었다. 이러한 연구결과는 소비자의 연 령에 따른 발 형태의 특징을 고려한 신발 설계에 기 초자료로의 의미가 있을 것으로 사료된다. 본 연구 는 수도권 지역으로 국한된 청년층과 중노년층 남 성을 대상으로 분석한 결과이므로 일반화하는데 신 중을 기해야 한다. 따라서 후속연구에서는 좀 더 광 범위한 지역의 청년층과 중노년층 남성을 대상으로 하는 연구가 추진되어져야 할 것이다. 또한 본 연구 의 청년층과 중노년층 남성의 발 형태 유형별 특징 에 관한 분석 결과를 신발 설계에 적용하는 연구가 추진되어져야 할 것이다.

\section{References}

Choi, J. M., Kweon, S. A., \& Kim, J. S. (2004). Footwear wearing practices and overall shoes satisfaction for males. Journal of the Korean Home Economics Association, 42(10), 53-61.

Choi, S. H., \& Chun, J. S. (2007). The comparison of foot shape classification methods. The Research Journal of the Costume Culture, 15(2), 252-264.

Chun, J. S., \& Choi, S. H. (1999). A study on foot shape of women in Korea. Journal of the Ergonomics Society of Korea, 18(1), 109-120.

Kim, N. S., \& Do, W. H. (2014). Classification of elderly men's foot side type from 3D scan data. 
Journal of the Korean Society of Clothing and Textiles, 38(4), 427-439. doi:10.5850/JKSCT.2014. 38.4.427

Kim, S. N. (2000). A survey on shoes wearing and a proposal regarding shoes size and shape improvement: Focused on women in their teens and twenties. Unpublished master's thesis, Ewha Woman's University, Seoul, Korea.

Korean Agency for Technology and Standards. (2010). 제6차 한국인 인체치수 3 차원형상측정 조사사 업 [3D body shape measurement project report of the 6th Size Korea project]. Size Korea, Retrieved June 9, 2015, from http://sizekorea. kats.go.kr/02_data/outline.asp

Kweon, S. A., Choi, J. M., \& Kim, J. S. (2005). A study on the wearing conditions and factors of discomfort with shoes for male college students. Journal of the Korean Society of Clothing and Textiles, 29(1), 79-90.

Lee, J. E. (1993). An empirical study on the apparel purchase behavior of middle and old ages. Unpublished master's thesis, Sang Myung Women's University, Seoul, Korea.

Lee, J. E., \& Kwon, Y. A. (2008). The classification of men's foot shape according to age. Fashion \& Textile Research Journal, 10(5), 644-651.

Lee, O. H. (1996). The relationship between level of clothing involvement and use of information sources of middle-elderly women. Journal of the Korean Home Economics Association, 34(2), 99116.

Lee, S. Y., \& Chun, J. S. (2015). The upper body type classification of middle-aged and elderly Korean women. The Research Journal of the Costume Culture, 23(3), 512-522. doi:10.7741/rjcc.2015.23. 3.512

Lim, J. Y., \& Choi, S. W. (2005). The classification of foot types of junior high school boys for the development of shoes' easy-order prototype. Fashion \& Textile Research Journal, 7(5), 535-541.

Moon, M. O. (1997). A study on the property of the foot form of early childhood children from three to six years old(II): On the classification of foot type. Journal of the Korean Society of Clothing and Textiles, 21(1), 144-154.

Park, J. K., \& Nam, Y. J. (2004). Characteristics of elderly women's foot shape compared with young women. Journal of the Korean Society of Clothing and Textiles, 28(11), 1495-1506.

Park, M. A. (2002). A study on the character for the foot and calf growth of primary school children. Fashion \& Textile Research Journal, 4(2), 163-168.

Seok, H. J., \& Park, J. E. (2007). The classification of elderly men's feet: With the three-dimensional body scanner data of Size Korea. Journal of the Korean Society of Costume, 57(10), 50-59.

Seok, H. J., Park, J. E., Han S. H., \& Kim, D. H. (2009). A study on the comparison of foot type for the men in their 20's and 60's: With the usage of Size Korea's 3-dimensional measurement data. Journal of the Korea Fashion \& Costume Design Association, 11(2), 183-195.

Shin, S. W., \& Hahm, O. S. (1999). Classification of foot type and the characteristics according to types. The Research Journal of the Costume Culture, 7(1), 38-51. 